\title{
Filsafat Metode Mengajar Omar Mohammad Al-Toumy Al- Syaibany dan Implikasinya Dalam Pembelajaran Pendidikan Agama Islam di Sekolah Dasar
}

\author{
Tatang Hidayat ${ }^{1}$, Syahidin $^{2}$, Ahmad Syamsu Rizal $^{3}$ \\ email : tatanghidayat@arraayah.ac.id ${ }^{1,}$ email : syahidin@ upi.edu $^{2}$,email : \\ rizal@upi.edu ${ }^{3}$ \\ Sekolah Tinggi Ilmu Bahasa Arab Ar Raayah, Sukabumi ${ }^{1}$ \\ Universitas Pendidikan Indonesia, Bandung ${ }^{2,3}$
}

\begin{abstract}
Abstrak: Fenomena dunia pendidikan yang sudah memasuki era revolusi industri 4.0 menuntut guru untuk meningkatkan 4 kompetensi yang harus dimiliki, yaitu kompetensi kepribadian, kompetensi profesional, kompetensi pedagogik dan kompetensi sosial. Namun temuan di lapangan masih banyak guru yang belum menguasai kompetensi pedagogik, terutama guru Pendidikan Agama Islam yang masih kekurangan metode mengajar berlandaskan filsafat pendidikan Islam. Tujuan penelitian ini untuk mendeskripsikan filsafat metode mengajar Omar Mohammad al-Toumy al-Syaibany dan implikasinya dalam pembelajaran Pendidikan Agama Islam di Sekolah Dasar. Penelitian ini menggunakan pendekatan kualitatif dan metode studi literatur. Teknik pengambilan data dengan mengumpulkan dari dua acuan sumber data yakni data primer sebagai data utama yang dicari dan data sekunder sebagai data pendukung. Teknik analisis data dengan interpretasi data. Berdasarkan hasil penelitian, filsafat metode mengajar dalam pendidikan Islam menurut al-Syaibany terdiri dari konsep metode mengajar dan pentingnya dalam pendidikan Islam, jenis-jenis metode mengajar dalam pendidikan Islam, metode mengajar umum yang terpenting dalam pendidikan Islam, ciri-ciri dan tujuan umum metode mengajar dalam pendidikan Islam, asas-asas umum metode mengajar dalam pendidikan Islam dan prinsip-prinsip umum yang menjadi dasar metode mengajar dalam pendidikan Islam. Filsafat metode mengajar dalam pendidikan Islam menurut al-Syaibani bisa dijadikan alternatif solusi untuk mengisi kekurangan metode pembelajaran Pendidikan Agama Islam, karena memiliki landasan filosofis yang kuat Implikasinya, filsafat metode mengajar dalam pendidikan Islam menurut alSyaibany ini mesti dipelajari, dipahami, dihayati, dikembangkan dan diimplementasikan dalam pembelajaran Pendidikan Agama Islam. Salah satunya melalui lembaga pendidikan formal jenjang sekolah dasar yang memiliki peran sangat sentral dalam membina akhlak peserta didik.
\end{abstract}

Kata kunci: Al-Syaibany, Filsafat, Metode Mengajar, Pendidikan Agama Islam, Sekolah Dasar 
Tatang, Syahidin, Ahmad. Filsafat Metode Mengajar Omar...

\title{
PHILOSOPHY OF THE TEACHING METHOD OF OMAR MOHAMMAD AL-TOUMY AL-SYAIBANY AND ITS IMPLICATIONS IN LEARNING ISLAMIC EDUCATION IN ELEMENTARY SCHOOLS
}

\begin{abstract}
The education realm has entered the era of industrial revolution 4.0. Due to this phenomenon, teachers are required to improve and possess 4 competencies, namely personality competence, professional competence, pedagogic competence, and social competence. However, based on the findings, there are still many teachers who have not mastered pedagogical competencies, especially Islamic Religious Education teachers who still lack teaching methods based on the philosophy of Islamic education. The purpose of this study is to describe the philosophy of the teaching method in Islamic education according to Omar Mohammad al-Toumy al-Syaibany and its implications on the learning of Islamic Religious Education in Elementary Schools. This study employed a qualitative approach with literature study method. The data collection techniques include collecting data from two sources namely primary data, as the main sought-after data, and secondary data as supporting data. The data are interpreted through data analysis techniques. Based on the results of the research, AlSyaibani's philosophy on the teaching method in Islamic education can be used as an alternative solution to fill the shortcomings in the learning methods of Islamic Religious Education for it has a strong philosophical foundation. The implications therefore, the philosophy must be studied, understood, internalized, developed, and implemented in the Islamic Religious Education learning. One of the implementation techniques is through formal education institutions, namely in elementary schools as they have a very central role in fostering akhlaq of students.
\end{abstract}

Keywords: Al-Syaibany, Elementary School, Islamic Religious Education,Philosophy, and Teaching Method

\section{PENDAHULUAN}

Semakin pesatnya ilmu pengetahuan dan teknologi yang disertai cepatnya arus informasi akan mempengaruhi norma-norma yang berlaku di masyarakat. Oleh karena itu, pendidikan sebagai sarana dalam pengembangan potensi manusia yang merupakan bagian dari masyarakat didalamnya dituntut untuk melakukan pengembangan supaya selaras dengan kebutuhan masyarakat. Herman (2014) mencatat pendidikan merupakan usaha untuk menumbuhkan dan mengembangkan potensi manusia yang terdiri dari jasmani dan rohani sesuai dengan norma-norma yang berlaku di masyarakat.

Fenomena kemajuan ilmu pengetahuan dan teknologi yang semakin pesat mesti disikapi para ahli pendidikan dengan melahirkan inovasi-inovasi terbaru, apalagi saat ini sudah memasuki era revolusi industri 4.0, era dimana segala sesuatunya sudah 
Tatang, Syahidin, Ahmad. Filsafat Metode Mengajar Omar...

berpindah ke dalam teknologi digital. Pendidikan Islam sebagai sebuah konsep yang memiliki ciri khas dari konsep pendidikan pada umumnya mesti mengalami pengembangan, baik dari segi konsep hingga metode pendidikannya. Mardeli (2011) mengobservasi bahwa metode merupakan alat yang sangat penting untuk mencapai tujuan pendidikan. Setiap guru mesti mengetahui, memahami, dan menguasai metode pendidikan, karena dengan menggunakan metode yang tepat akan menentukan keberhasilan pendidikan.

Namun, kenyataan di lapangan masih ditemukan para guru yang kurang memperhatikan metode yang digunakannya, salah satunya saat proses pembelajaran di dalam kelas, kalau pun menggunakan metode tertentu cenderung metode tersebut sudah sangat klasik untuk terus dipraktikkan dan dipertahankan di masa kini (Fikri, 2011). Problematika tersebut terjadi juga pada guru Pendidikan Agama Islam (PAI), metode pendidikan yang digunakan cenderung belum menyesuaikan dengan perkembangan zaman, sehingga belum memberikan makna dalam proses pembelajaran.(Hidayat \& Kosasih, 2019).

Salah satu penyebab penggunaan metode pembelajaran guru PAI cenderung belum menyesuaikan dengan perkembangan zaman karena masih minimnya literatur tentang filsafat pendidikan Islam terutama berkaitan dengan metode mengajar. Hasib (2014) menegaskan hal ini terjadi karena adanya kesenjangan proses berfikir dalam metodologi, sehingga orang Islam masih menginduk kepada barat dalam mengembangkan ilmu. Salah satu tantangan dunia pendidikan saat ini adalah model pembelajaran filsafat ilmu yang masih belum tampak berwarna Islam. Hal ini bisa dipahami dari fenomena minimnya buku-buku teks filsafat ilmu dengan menggunakan perspektif pandangan hidup Islam.

Sementara itu, adanya kecenderungan persoalan filosofis ketika membahas filsafat pendidikan Islam, seolah kalangan ahli pendidikan Islam tidak punya kuasa untuk melakukan perlawanan terhadap pengembangan ilmu pengetahuan yang dikembangkan oleh dunia barat. Hal tersebut disebabkan karena dalam filsafat pendidikan Islam mengkaji 3 bahasan sekaligus, yakni filsafat sebagai bahasan teoritik, pendidikan sebagai bahasan praktis, dan Islam sebagai bahasan ideal, sehingga untuk menyatukan ketiga bahasan tersebut terkadang mengalami kesulitan. 
Tatang, Syahidin, Ahmad. Filsafat Metode Mengajar Omar...

Di sisi lain, mekanisme perolehan ilmu dalam perspektif filsafat pendidikan Islam meliputi beberapa hal: Pertama, mekanisme perolehan ilmu melalui indera/pengalaman; Kedua, mekanisme perolehan ilmu melalui akal; ketiga, mekanisme perolehan ilmu melalui ilham dan wahyu. Mekanisme-mekanisme perolehan ilmu ini membawa beberapa implikasi penting dalam filsafat pendidikan Islam, khususnya adalah pada teori belajar (Ulfah, 2012).

Berdasarkan beberapa penyebab yang ada, dapat diambil satu untuk dikaji sebagai upaya menyelesaikan salah satu problematika yang ada, yakni masih minimnya literatur metode pembelajaran dalam kajian pendidikan Islam. Jika problematika minimnya literatur yang menjelaskan tentang berbagai konsep pendidikan Islam dengan didasari filsafat yang menguatkannya dibiarkan saja, tentu akan menyebabkan problematika dalam pengembangan pendidikan Islam itu sendiri. Nantinya para ahli pendidikan Islam akan mengembangkan konsep pendidikan Islam dengan menggunakan metode yang tidak sesuai dengan Islam, hasilnya tentu tidak akan ditemukan sebuah kesatuan pengembangan yang utuh. Hidayat, Rizal, \& Fahrudin (2018a) mengkaji metode pendidikan Islam merupakan semua cara khas dalam Islam yang digunakan dalam mendidik untuk mencapai tujuan pendidikan Islam. Metode pendidikan Islam sangat berbeda dengan metode pendidikan Barat.

Perlu ada suatu upaya untuk menghadirkan literatur metode pembelajaran dalam pendidikan Islam. Upaya tersebut diharapkan bisa menjembatani kesenjangan yang ada. Dari sekian banyak literatur yang membahasan filsafat pendidikan Islam, menarik kiranya jika kita mengkaji sebuah kitab yang membahas tentang filsafat pendidikan

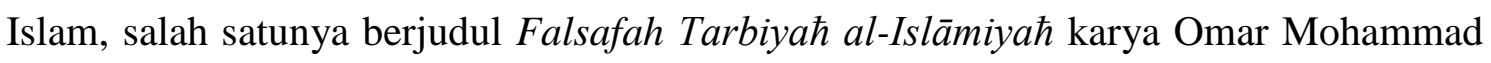
al-Toumy al-Syaibany .

Penulis berasumsi dari beberapa literatur yang membahas filsafat pendidikan Islam, karya al-Syaibany ini cukup komprehenshif dalam menghadirkan kajiannya. Salah satunya ada pembahasan mengenai filsafat metode pembelajaran dalam pendidikan Islam (al-Syaibany, 1983). Oleh karena itu, dalam penelitian ini penulis mengangkat judul Filsafat Metode Mengajar Omar Mohammad al-Toumy al-Syaibany dan Implikasinya dalam Pembelajaran Pendidikan Agama Islam di Sekolah Dasar. Tujuan penelitian ini untuk mendeskripsikan filsafat metode mengajar Omar Mohammad al- 
Tatang, Syahidin, Ahmad. Filsafat Metode Mengajar Omar...

Toumy al-Syaibany dan implikasinya dalam pembelajaran Pendidikan Agama Islam di Sekolah Dasar.

\section{METODE}

Penelitian ini menggunakan pendekatan kualitatif dan metode studi literatur. Hidayat \& Asyafah (2018) dalam metodologi penelitian dengan menggunakan paradigma Islam, penelitian ini termasuk menggunakan metode tajribi yakni metode penelitian selain memerankan kemampuan berfikir juga dilanjutkan dengan tindakan eksperimen, observasi, dan bentuk-bentuk metode yang dikenal dengan metodologi ilmiah seperti kualitatif, kuantitatif dan metode campuran antara keduanya.

Teknik pengambilan data dengan mengumpulkan dari dua acuan sumber data yakni data primer sebagai data utama yang dicari dan data sekunder sebagai data pendukung.

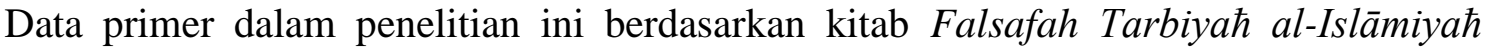
karya al-Syaibany. Adapun data sekunder dalam penelitian ini berdasarkan edisi

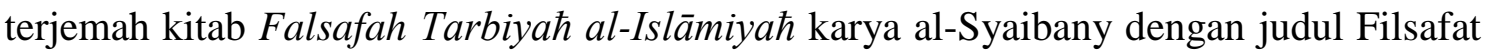
Pendidikan Islam. Data sekunder dilengkapi dengan buku pendidikan Islam karya para ahli lainnya, jurnal yang diakses secara online, hasil forum seminar dan diskusi dengan ahli yang relevan dengan problematika yang ditemukan.

Data-data yang sudah diperoleh kemudian dianalis dengan teknik analisis isi, interpretasi data, kemudian penulis memberikan pemahaman dan penjelasan secukupnya. Data-data yang diperoleh, penulis analisis dan didukung oleh teori-teori yang otoritatif tentang metode pembelajaran dan pendidikan.

\section{HASIL DAN PEMBAHASAN}

\section{A. Konsep Metode Mengajar dan Pentingnya dalam Pendidikan Islam}

Metode merupakan bagian dari komponen pendidikan. Metode adalah implementasi dari sebuah kurikulum untuk mencapai tujuan kurikulum yang dirumuskan. Al-Syaibany (1979:552) sendiri menyimpulkan bahwa metode mengajar terdiri dari beberapa definisi : Pertama, metode mengajar adalah jalan seorang guru untuk memberikan pemahaman kepada murid dan merubah tingkah lakunya sesuai dengan tujuan-tujuan yang diinginkan. Kedua, metode mengajar memiliki arti lebih dari hanya sekedar alat mengajar saja, tetapi lebih tepatnya lagi sebagai alat bantu murid 
Tatang, Syahidin, Ahmad. Filsafat Metode Mengajar Omar... untuk menerima maklumat dan pengetahuan. Selain itu, ia juga bermakna sebagai alat untuk menolong pelajar dalam memperoleh keterampilan, kebiasaan, sikap, minat, nilainilai yang diinginkan. Semua itu dilakukan dalam proses pendidikan dan proses pembelajaran yang menjadi suatu bagian yang tak terpisah dari proses pendidikan.

Perubahan yang diinginkan pada tingkah laku pelajar adalah tujuan asasi bagi proses pembelajaran. Keberhasilan pembelajaran dan metodenya hanya dapat diukur menurut kadar dan kualitas proses belajar yang dihasilkan oleh pembelajaran pada peserta didik. Kegiatan pembelajaran merupakan kegiatan terarah dan sekaligus mempunyai berbagai segi yang bertujuan untuk mencapai proses belajar yang diinginkan. Diantara kegiatan-kegiatan yang terkandung di dalamnya ialah bercakap, berbincang, menggambarkan, menjelaskan, mencontohkan, menulis, membimbing, membanding, meneliti, mengambil kesimpulan dan masih banyak lagi yang berkaitan dengan kegiatan kegiatan dalam proses pembelajaran (Al-Syaibany, 1979:553).

Metode pembelajaran adalah suatu proses yang terdiri dari beberapa langkah. Antara langkah-langkah dan unsur-unsur yang digunakan pada metode tertentu dalam pembelajaran dapat digunakan juga pada metode-metode yang lain. Mengaitkan unsurunsur ini dalam suatu proses yang dinamis itulah tanggung jawab utama seorang guru. Fungsi metode pendidikan Islam sendiri adalah penghubung antara pendidik dan peserta didik dalam proses transfer pengetahuan dari sarana pengetahuan ke dalam pemahaman peserta didik. Walaupun banyak pendapat-pendapat modern yang mengatakan bahwa proses belajar-mengajar bukan hanya transfer pengetahuan, tetapi kita tidak bisa menafikan fungsi dari metode pendidikan sebagai penghubung transfer pengetahuan dari sumber pengetahuan kepada peserta didik tersebut (Al-Syaibany, 1979:554).

Metode pendidikan Islam sendiri sangat penting peranannya dalam proses pembelajaran, karena tanpa metode tidak akan ada kegiatan timbal balik antara guru dan murid, inilah alasan yang menjadi penunjang cara pandang kita kepada fungsi metode pendidikan Islam. Pendidik pendidikan Islam adalah orang pertama yang menekankan pentingnya metode pembelajaran dan menentukan prinsip-prinsip dan syarat-syarat yang harus dipelihara dalam metode mengajar, dialog, perdebatan dan pelajaran (AlSyaibany, 1979:554).

Berdasarkan uraian di atas, dapat dipahami bahwa metode pembelajaran merupakan suatu proses yang terdiri dari langkah-langkah yang berfungsi sebagai penghubung 
Tatang, Syahidin, Ahmad. Filsafat Metode Mengajar Omar...

antara pendidik dan peserta didik dalam proses transfer pengetahuan, sikap, dan keterampilan.

\section{B. Jenis - Jenis Metode Pendidikan Islam}

Tidak ada satu metode mengajar yang sama untuk semua tujuan pendidikan, ilmu, mata pelajaran, tahap perkembangan, tahap pembelajaran, tahap kematangan, tahap kecerdasan, untuk semua keadaan dan suasana yang meliputi proses-proses pembelajaran. Tidak ada jalan untuk memaksakan metode tertentu kepada guru-guru baik pada pendidikan Islam maupun pendidikan modern. Guru dalam pendidikan Islam adalah pencipta metode mengajarnya. Oleh sebab itu, haknya untuk memilih metode yang sesuai dengan tujuan pendidikan yang ingin dicapainya (Al-Syaibany, 1979, hal. $557)$.

Berdasarkan pertimbangan itulah maka ada jenis-jenis metode dan cara-cara mengajar baik dalam buku-buku pendidikan Islam maupun pendidikan modern. Berikut jenis-jenis dan penguraiannya yang dikemukan oleh al-Syaibany (1979:558):

1. Metode yang berdasarkan alat-alat dan bahan-bahan yang digunakan padanya, seperti metode kitab, metode laboratorium dan lain sebaginya.

2. Metode yang berdasarkan pada cara yang diikutinya dalam menemukan fakta, seperti metode lawatan ilmiah, metode pelajaran, metode pasrtisipasi untuk lathan dan lain-lain.

3. Metode yang berdasarkan pada penyusunan mata pelajaran, seperti metode penyusunan masa, metode penyusunan psikologik, metode penyusunan logik, metode penyusunan mengikuti perkara, metode pengembangan pengalaman dan lain sebagainya.

4. Metode berdasarkan pada tujuan yang dituju oleh guru, seperti metode nasihat, metode petunjuk, metode bimbingan, metode latihan, metode menikmati, metode apresiasi, metode pemikiran, metode kesimpulan, metode analisa, metode penafsiran dan metode pengembangan pengalaman.

5. Metode yang berdiri atas tujuan murid, seperti metode penyelesaian masalah dan metode proyek. 
Tatang, Syahidin, Ahmad. Filsafat Metode Mengajar Omar...

6. Metode yang berdasarkan pada hubungan timbal-balik antara murid dan guru, seperti metode pengakatan, metode pelajaran terarah, dan metode proyek yang dipilih dengan bebas.

7. Metode berdasarkan pada hubungan timbal-balik antara murid satu dengan yang lainnya, seperti metode kegiatan perseorangan, metode kegiatan panitia, dan metode kegiatan kerjasama (cooperation).

8. Metode berdasarkan pada tingkat keikutsertaan murid pada proses pendidikan, seperti metode persembahan bersama murid, metode keikutsertaan tersusun dari murid-murid, metode memperdengarkan bersama dan metode kegiatan dari pihak murid.

9. Metode yang berdasarkan pada tingkat kebebasan berfikir, seperti metode intruksi, metode pengambilan kesimpulan dari awal, metode pengambilan kesimpulan terpimpin dan metode percobaan.

10. Metode yang berdasarkan pada cara yang digunakan dalam ulangan dan penilaian, seperti metode lisan, metode laporan tertulis dan metode ujian tertulis.

11. Metode yang berdasarkan pada pancaindra luar, seperti metode penglihatan, metode pendengaran dan metode gerakan.

\section{Metode Mengajar Umum yang terpenting dalam Pendidikan Islam}

Kitab-kitab pendidikan Islam mengandung banyak gambaran dan uraian tentang metode serta cara mengajar umum yang telah digunakan oleh para pendidik Islam. AlSyaibany (1979:560-581) mencatat dalam bukunya bahwa metode umum yang paling menonjol dapat disebutkan secara ringkas sebagai berikut: Metode pengambilan kesimpulan atau induktif, metode perbandingan (Qiyāsiah), metode kuliah, metode dialog, metode perbincangan, metode lingkaran (halqah), metode riwayat, metode mendengar, metode membaca, metode imla' (dictation), metode hafalan, metode pemahaman, dan metode lawatan untuk menuntut ilmu.

\section{Ciri - Ciri dan Tujuan Umum Metode Mengajar Dalam Pendidikan Islam}

\section{Ciri-Ciri Metode Mengajar dalam Pendidikan Islam}

a. Berpadunya metode dan cara-cara dari segi tujuan dan alat, dengan jiwa ajaran dan akhlak Islam yang mulia. 
Tatang, Syahidin, Ahmad. Filsafat Metode Mengajar Omar...

b. Bersifat fleksibel, dapat menerima perubahan, penyesuaian sesuai dengan keadaan dan suasana serta mengikuti sifat pelajar.

c. Metode tersebut berusaha sungguh-sungguh mengaitkan antara teori dan praktek, proses belajar dan amal, riwayat dan pemahaman, hafalan dan pemahaman, imla' dan ijtihad, memelihara pusaka generasi terdahulu yang saleh dan pembaharuan serta daya cipta, memelihara hafalan, aktivitasnya, kemampuan berfikir, menekankan peranan positif guru-guru, pentingnya penggunaan aktivitas murid dalam memperoleh ilmu dan keterampilan.

d. Membuang cara-cara meringkaskan dalam pembelajaran dan menganggap bahwa ringkasan ini adalah penyebab rusaknya kebolehan-kebolehan ilmiah yang berguna.

e. Menekankan kebebasan murid-murid berdiskusi, berdebat, berdialog dalam batasbatas kesopanan dan saling menghormati.

f. Ia juga mengangkat derajat guru dan meletakkannya dalam tingkat pimpinan, teladan dalam bidang fikiran, spiritual, memberinya hak penghargaan, penghormatan serta mengajak murid-murid patuh dan mendengar pendapatnya (AlSyaibany, 1979:583-584).

\section{Tujuan Umum Metode-Metode Mengajar dalam Pendidikan Islam}

a. Menolong pelajar untuk mengembangkan pengetahuan, maklumat, pengalaman, keterampilan sikapnya, terutama keterampilan berfikir ilmiah yang betul, sikap dalam bentuk cinta ilmu, suka menuntutnya, membuka rahasianya, merasa enak dan nikmat dalam mencarinya.

b. Membiasakan pelajar menghafal, memahami, berfikir sehat, memperhatikan dengan tepat, mengamati dengan tepat, rajin, sabar, teliti dalam menuntut ilmu, mempunyai pendapat yang berani, asli dan bebas.

c. Memudahkan proses pembelajaran itu bagi pelajar, membuatnya mencapai sebanyak mungkin tujuan yang diinginkan, menghemat tenaga dan waktu yang diperlukan untuk mencapainya.

d. Menciptakan suasana yang sesuai bagi pembelajaran yang berlaku sifat saling mempercayai, menghormati antara guru dan murid serta hubungan baik antara keduanya, juga meningkatkan semangat belajar, menggalakkannnya belajar dan bergerak (Al-Syaibany, 1979:585-586). 
Tatang, Syahidin, Ahmad. Filsafat Metode Mengajar Omar...

E. Asas - Asas Umum Metode Mengajar dalam Pendidikan Islam

\section{Dasar Agama}

Dasar agama ini adalah prinsip-prinsip, fakta-fakta umum yang pada dasarnya diambil dari teks agama Islam, syariat pada sumbernya yang induk dan cabang yang bermacam-macam, juga dari peninggalan dan amalan generasi terdahulu yang saleh. Pendidik muslim megambil banyak cara-cara, tujuan-tujuan, dan prinsip-prinsip pembelajarannya dari kitab Allah, Sunnah Nabi-Nya, juga dari perkataan dan amalan para ulama dan dari generasi terdahulu yang saleh (Al-Syaibany, 1979:586).

\section{Dasar Bio-Psikologis}

Dasar ini kelihatan pada dasar bio-psikologis yang bermakna sekumpulan kekuatan dari ciri-ciri jasmaniah, dan psikologis yang mempengaruhi tingkah laku pelajar pada proses belajarnya :

\section{a. Dasar Biologis}

Dasar biologis adalah kewajiban guru untuk memelihara dalam metode teknik pembelajarannya, ciri-cirinya, kebutuhan-kebutuhan jasmaniah, dan tahap kematangan muridnya (Al-Syaibany, 1979:589).

\section{b. Dasar Psikologis}

Tentang dasar psikologis maka yang dimaksudkan adalah sejumlah kekuatan psikologis termasuk motivasi, kebutuhan, emosi, minat, sikap, keinginan, kesediaan, bakat-bakat, dan kecakapan akal (intelektual). Sebagaimana guru harus menjaga kesediaan dan keterampilan murid dari segi jasmani ia juga harus menjaga kekuatankekuatan emosi, kesediaan-kesediaan dan kecakapan intelektualnya, karena tingkah lakunya secara umum, kegiatan, dan proses belajarnya secara khas sangat terpengaruh oleh faktor-faktor psikologis (Al-Syaibany, 1979:590).

\section{c. Dasar Sosial}

Seharusnya metode mengajarnya selaras dengan nilai-nilai masyarakat, tradisitradisinya yang baik, tujuan, kebutuhan, harapan terhadap anggota-anggotanya dan tuntutan-tuntutan kehidupan yang berjaya dalam masyarakat tersebut (Al-Syaibany, 1979: 591). 
Tatang, Syahidin, Ahmad. Filsafat Metode Mengajar Omar...

F. Prinsip - Prinsip Umum yang menjadi Dasar Metode Mengajar dalam Pendidikan Islam

Prinsip-prinsip yang menjadi dasar metode mengajar dalam pendidikan Islam sebagai berikut :

1. Pentingnya menjaga motivasi pelajar, kebutuhan, minat, dan keinginannya pada proses belajar. Sebab menggerakkan motivasi yang terpendam ini, menjaganya dalam pengalaman-pengalaman yang diajukan kepada pelajar, berbagai aktivitas yang diminta pelajar melakukannya, juga metode dan cara-cara yang menemaninya, menjadikan pelajar lebih ingin belajar lebih aktif.

2. Pentingnya menjaga tujuan belajar dan menolongnya mengembangkan tujuan tersebut. Semua itu adalah tugas guru untuk menolong muridnya utuk menentukan tujuannya dalam belajar, menjaga tujuan dalam proses pembelajaran, dan membimbing murid supaya ia lebih suka kepada pelajaran.

3. Kemestian memelihara tahap kematangan yang dicapai oleh pelajar dan derajat kesediaannya untuk belajar. Oleh sebab itu, ia mengajarkan mereka sesuai dengan tahap kematangan jasmani, akal dan emosi mereka. Memulai dari yang telah diketahui kepada yang belum diketahui, dari yang konkrit kepada abstrak, dari sederhana kepada yang kompleks, dari yang umum kepada yang khas, dari yang mudah kepada yang susah.

4. Perlu menjaga perbedaan karakter yang dimiliki di antara para pelajar

5. Pendidik seharusnya mempersiapkan peluang partisipasi yang praktikal.

Dapatlah prinsip yang dipegang oleh pendidik muslim dalam metode pembelajaran mereka bercabang-cabang kepada empat prinsip yang berkaitan dan saling melengkapi satu sama lain. Empat prinsip itu adalah : Pertama, prinsip partisipasi. Kedua, prinsip penaksiran (diagnose) makna, penjelasan yang konkrit terhadap pengetahuan dan faktafakta yang dipelajari. Ketiga, prinsip pengulangan yang terpimpin. Keempat, prinsip teladan yang baik dan mengamalkan sendiri apa yang diajarkannya.

6. Prinsip memperhatikan kepahaman, mengetahui hubungan, kepaduan, kelanjutan pengalaman, sifat baru, dan keaslian kebebasan berfikir.

7. Pentingnya membuat proses pendidikan yang menggembirakan dan menciptakan kesan yang baik pada diri pelajar (Al-Syaibany, 1979:595-624). 
Tatang, Syahidin, Ahmad. Filsafat Metode Mengajar Omar...

\section{G. Implikasinya terhadap Pembelajaran Pendidikan Agama Islam di Sekolah}

\section{Dasar}

Metode pembelajaran dalam pendidikan Islam sebagaimana yang digagas alSyaibany memiliki landasan filosofis yang kuat dan komprehensif. Muslih (2011) mencatat bahwa proses dan hasil keilmuan sangat ditentukan oleh landasan filosofisnya, yang meliputi kerangka teori, paradigma keilmuan dan asumsi dasar. Ketiga hal ini menjadi basis filosofis yang berfungsi memberikan kerangka, arahan serta corak keilmuan yang dihasilkan. Islamic wordlview dalam perspektif filsafat ilmu, pada dasarnya merupakan asusmsi teologis-metafisis atau hal yang menjadi ciri khas yang membedakannya dengan pendidikan sekuler.

Oleh karena itu, filsafat pendidikan Islam gagasan al-Syaibany bisa memberikan kontribusi dalam meningkatkan proses pembelajaran, salah satunya dalam pembelajaran PAI di Sekolah Dasar (SD) supaya bisa lebih bermakna. Hidayat \& Syahidin (2019a) meneliti bahwa pendidikan modern sudah kehilangan makna esensial pendidikan itu sendiri. Juwariyah (2004) menegaskan dalam menghadapi era globalisasi dimana arus kebudayaan Barat melalui berbagai media dengan derasnya mengalir ke bumi Indonesia, menuntut kita untuk mengantisipasi membanjirnya budaya Barat tersebut yang terkadang bertentangan dengan budaya bangsa dan terlebih norma agama kita, dengan menemukan kembali epistemologi Islam dan menerapkannya dalam pengembangan masyarakat bangsa melalui jalur pendidikan, yakni dengan memberikan nafas Islam dalam seluruh aktivitas proses pendidikan, salah satunya metode pendidikan yang digunakan, karena hanya dengan cara itulah bangsa ini akan dapat diselamatkan

Metode pembelajaran yang digunakan pasti tidak akan terlepas dari landasan filosofisnya, maka dari itu gagasan metode pembelajaran al-Syaibany sangat penting untuk diimplementasikan di tengah problematika pelaksanaan pendidikan modern saat ini. Keingintahuan manusia terhadap segala sesuatu yang baru mesti diimbangi dengan metode yang selaras untuk memenuhi pengetahuannya. Arfa (2015: 1) menemukan pengetahuan dimulai dari rasa ingin tahu, yang merupakan ciri khas manusia karena manusia merupakan makhluk yang tidak pernah puas dalam mengembangkan pengetahuan yang dilakukan secara sungguh-sungguh.

Mujib (2008:165) mencatat bahwa materi yang benar dan baik tanpa menggunakan metode yang baik maka akan menjadikan keburukan materi tersebut. Kebaikan materi 
Tatang, Syahidin, Ahmad. Filsafat Metode Mengajar Omar...

harus ditopang dengan kebaikan metode juga. Fikri (2011) mengobservasi ada beberapa metode pembelajaran yang dapat dipraktikkan di dalam proses belajar mengajar pada lembaga pendidikan Islam, antara lain: metode ceramah, metode diskusi atau musyawarah, metode demonstrasi atau eksperimen, metode insersi (sisipan/lampiran), metode wrapping (menyelubung) dan, metode inquiry.

Namun Syahidin (2009:75) menemukan bertolak dari pemahaman tentang konsep pendidikan dalam perspektif Alquran, metode pendidikan Qurani merupakan suatu bagian penting dalam melaksanakan upaya pendidikan. Alquran telah menawarkan sejumlah cara dalam menyampaikan nilai-nilai pendidikan, baik dalam aspek pengembangan akal, perasaan, keterampilan, maupun aspek-aspek kemanusiaan lainnya.

Beberapa metode pendidikan yang dikemukakan dalam Alquran yaitu; metode ceramah, metode kisah, metode tanya jawab, metode penelitian, metode demonstrasi, metode hafalan, metode latihan, metode teladan, dan metode nasehat (Mardeli, 2011). Sementara itu, konsep metode pendidikan qurani yang digagas al-Nahlawi kemudian diturunkan lagi ke dalam tataran implementasi oleh Syahidin (2009) menghasilkan beberapa metode diantaranya metode kisah Qurani, metode jadal, metode hiwar, metode amsial metode targhib wa tarhib, metode uswatun hasanah, metode tajribi, dan metode mauiżoh hasanah.

Selain menggunakan metode pendidikan Qurani, dalam sistem pendidikan modern perlu juga mengaplikasikan metode pembiasaan (habituation) yang merupakan proses pembinaan sikap dan perilaku yang relatif menetap dan bersifat otomatis melalui proses pembelajaran yang berulang-ulang (Yapono, 2015 : Hidayat, Rizal, \& Fahrudin, 2018). Pemilihan metode mengajar yang tepat akan sangat berpengaruh kepada efektivitas pembelajaran. Ketepatan penggunaan metode mengajar tersebut dipengaruhi oleh banyak faktor. Diantaranya: sifat dari tujuan yang hendak dicapai, keadaan peserta didik, bahan pembelajaran dan situasi belajar mengajar sebagaimana al-Syaibani telah menjelaskan pula (Nasih, 2009:39).

Namun selain penggunaan metode pendidikan yang baik, perlu juga memperhatikan komponen pendidikan lainnya, yakni tujuan pendidikan, guru, anak didik, kurikulum, dan evaluasi. Salah satu bagian yang patut mendapat perhatian adalah masalah kurikulum (Rahman, 2012). Oleh karena itu kurikulum mesti dirumuskan dengan serius 
Tatang, Syahidin, Ahmad. Filsafat Metode Mengajar Omar...

untuk mencapai tujuan .pendidikan yang digagas, Sebagai alat, tentunya pendidikan merupakan aplikasi dari kebudayaan yang berposisi tidak netral, melainkan selalu bergantung pada siapa dan bertujuan apa pendidikan itu dilaksanakan (Syihabuddin, 2017). Oleh karena itu, tujuan pendidikan mesti dirumuskan dan dilandasi dengan filosofis pendidikan yang kuat, salah satunya berdasarnya filsafat pendidikan Islam (Hidayat \& Syafe'i, 2018a).

Filsafat pendidikan Islam bertujuan: Pertama, membantu para perancang dan pelaksana pendidikan dalam membentuk pemikiran yang benar terhadap proses pendidikan. Kedua, memberi dasar bagi pengkajian pendidikan secara umum dan khusus. Ketiga, menjadi dasar penilaian pendidikan secara menyeluruh. Keempat, memberi sandaran intelektual, bimbingan bagi pelaksana pendidikan dalam menghadapi tantangan. Kelima, memberikan pendalaman pemikiran tentang pendidikan dalam hubungannya dengan faktor-faktor spiritual, kebudayaan, sosial, ekonomi, politik dan berbagai aspek kehidupan (Mukalam, 2013).

Pendidikan Islam memiliki peran yang sangat penting dalam keseluruhan hidup manusia. Pendidikan berintikan interaksi antar manusia, terutama antara pendidik dan terdidik demi mencapai tujuan pendidikan nasional. Dalam interaksi tersebut terlibat isi yang diinteraksikan serta proses bagaimana interaksi tersebut berlangsung. Apakah yang menjadi tujuan pendidikan, siapakah pendidik dan peserta didik, apa isi pendidikan dan bagaimana proses interaksi pendidikan tersebut, merupakan pertanyaan-pertanyaan yang membutuhkan jawaban yang mendasar, yang esensial, yakni jawaban-jawaban filosofis (Nursikin, 2016).

Salah satu bukti lembaga pendidikan Islam yang telah memberikan peran dalam pembangunan sumber daya manusia Indonesia yaitu pondok pesantren. Selain berfungsi sebagai lembaga pendidikan, pesantren juga berfungsi sebagai lembaga keagamaan yang menjadi basis terhadap segala bentuk penjajahan, lembaga keilmuan, lembaga penelitian, lembaga pelatihan, dan lembaga pengembangan masyarakat sekaligus menjadi simpul budaya (Hidayat, Rizal, \& Fahrudin, 2018b). Pondok pesantren dapat dijadikan contoh untuk mengembangkan pendidikan Islam karena konsep pendidikan Islam mesti dilandasi dengan filosofis yang berlandaskan nilai-nilai Islam, bukan dengan nilai-nilai sekuler sebagaimana yang kita temukan saat ini. 
Tatang, Syahidin, Ahmad. Filsafat Metode Mengajar Omar...

Perlu diakui beberapa praktik pendidikan Islam saat ini bergerak tanpa panduan filsafat pendidikan Islam (Tarbiyah), tetapi dipandu pemikiran sekuler sehingga tumbuh tanpa arah dan sulit bersaing. Karena itu sudah waktunya praktik pendidikan Islam

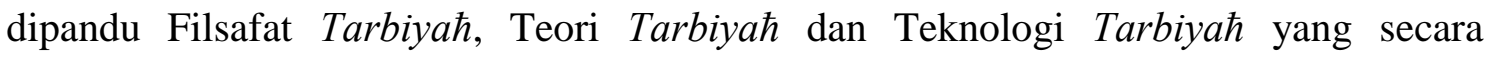
struktural dan fungsional dibangun dari Filsafat Islam (Mulkhan, 2013).

Paradigma pendidikan di Indonesia saat ini yang cenderung sekuler sudah saatnya diganti dengan paradigma Islam, yakni paradigma yang berdasarkan keagamaan, dan hal tersebut selaras dengan tujuan pendidikan nasional yang tercantum dalam UndangUndang No. 20 tahun 2003. Dalam undang-undang tersebut tercantum bahwa tujuan pendidikan nasional salah satunya dalam rangka menanamkan nilai-nilai keimanan, ketakwaan, dan akhlak mulia, oleh karena itu pelaksanaan pendidikan di Indonesia harus menjadikan keimanan, ketakwaan, dan akhla mulia sebagai inti yang mewarnai mata pelajaran apapun (Hidayat \& Suryana, 2018).

Di sisi lain, dalam konteks orientasi pendidikan modern saat ini sudah saatnya filsafat pendidikan Islam bisa memberikan kontribusi dalam perumusan landasan konseptual sistem pendidikan nasional. Selain itu dibutuhkan pula respons positif dari para pemikir dan pengelola pendidikan Islam untuk lebih meningkatkan kualitas pendidikan Islam yang pada gilirannya mampu memberikan kontribusi yang lebih besar terhadap pengembangan sistem pendidikan nasional (Tolchah, 2015).

Dalam tataran implementasi pendidikan Islam di lembaga pendidikan formal, pendidikan Islam harus menjadi proses dalam pembinaan insān kamil yang mampu memaksimalkan seluruh potensi manusia. Lazimnya metode pendidikan harus mencerminkan nuansa integratif-interkonektif yang mampu merangsang berkembangnya potensi secara maksimal (Rohinah, 2013).

Proses pembinaan manusia yang sempurna dan mulia tidak bisa dilakukan dengan cara yang mudah dan singkat, tetapi memerlukan proses yang panjang, dan tentunya mesti diawali sejak dini. Hidayat, Syahidin, \& Rizal (2019) supaya terwujud lulusan yang memiliki karakter akhlak mulia mesti difasilitasi oleh sistem pendidikan yang mampu mewujudkan ke arah sana, dan sistem pendidikan tersebut harus terlahir dari sistem kehidupan yang berdasarkan pemikiran, perasaan, dan aturan hidup yang sama, yakni Islam. Salah satu ikhtiar ke arah sana bisa dilakukan terlebih dahulu dengan 
Tatang, Syahidin, Ahmad. Filsafat Metode Mengajar Omar...

memasukan nilai-nilai Islam kepada komponen-komponen sistem pembelajaran, salah satunya metode mengajar.

Oleh karena itu, konsep filsafat metode mengajar dalam pendidikan Islam menurut Omar Mohammad al-Toumy al-Syaibany sebagai salah satu bagian dalam sistem pendidikan dan pembelajaran perlu dipelajari, dipahami, dihayati, dikembangkan dan diimplementasikan dalam pelaksanaan pendidikan modern yang sudah kehilangan makna esensial, salah satunya melalui lembaga pendidikan formal jenjang SD yang memiliki peran sangat sentral dalam membina akhlak peserta didik.

SD merupakan jenjang yang akan menentukan dalam pembinaan generasi bangsa ke depan, karena dalam jenjang ini perkembangan fisik dan mental anak sedang mengalami masa dimana otak dan mental anak mudah merekam segala apa yang didapatkannya. Oleh karena itu, pengetahuan, sikap, dan keterampilan yang didapatkan murid dari gurunya ketika jenjang SD akan mudah diingat dan diimplementasikannya. Dengan demikian, guru memiliki peran sentral dalam proses pembelajaran di jenjang SD, guru mesti menggunakan berbagai macam metode pembelajaran yang dapat meningkatkan motivasi siswa untuk belajar agama.

Ditinjau berdasarkan aspek metode, guru mesti mulai memberanikan diri menggunakan metode yang berasal dari pendidikan Islam, seperti metode pendidikan Qurani, metode riyadhoh, metode rihlah, metode talaqi, metode halqah dan yang lainnya (Hidayat \& Syafe'i, 2018b). Metode yang paling efektif digunakan dalam penanaman nilai-nilai keimanan, ketakwaan, dan akhlak mulia di SD adalah metode uswatun hasanah yang berdasarkan kasih-sayang, yang mana dalam metode ini guru PAI lah yang bertindak sebagai model untuk mencontohkan kepada murid segala sesuatu yang berkaitan dengan pengamalan agama. Apa yang disampaikan guru di kelas mesti selaras dengan pengamalan di lapangan, sehingga murid akan melihat dan merekam apa yang dilakukan oleh gurunya. Jika guru PAI sudah mencontohkan akhlak yang baik ketika mengajar atau pun tidak sedang mengajar, nantinya guru PAI akan menjadi sosok model yang diidolakan oleh muridnya, karena pendidikan modern saat ini sedang kehilangan sosok model yang layak untuk diteladani. Hidayat, Rahmat, \& Supriadi (2019) menegaskan guru mesti mengoptimalkan peranannya di sekolah sebagai sosok teladan dalam menanamkan nilai-nilai akhlak. 
Tatang, Syahidin, Ahmad. Filsafat Metode Mengajar Omar...

Untuk mencontohkan berkaitan dengan pengamalan ibadah, guru PAI bisa menggunakan metode tajribi, yakni metode pembelajaran dengan melakukan pengamalan yang nyata, bukan rekayasa sebagaimana model demonstrasi. Contohnya, guru PAI ingin membiasakan murid-murid untuk mengamalkan shalat dhuha, maka guru PAI bisa mengajak langsung murid-muridnya melakukan shalat dhuha di masjid dalam bentuk nyata. Begitupun dengan shalat dzuhur berjama'ah, membaca Alquran, pembacaan hadis, dan amalan-amalan lainnya. Awalnya memang akan dirasakan cukup berat ketika mengawali sesuatu yang baik, tetapi jika dilakukan secara istiqomah dan berjama'ah, pembiasan yang dilakukan nantinya akan terbiasa dan menjadi budaya di sekolah.

Sementara itu, untuk membangkitkan semangat siswa dan meningkatkan taraf berfikir dalam belajar agama, tidak salahnya guru PAI untuk sering-sering menggunakan metode rihlah ilmiah, yakni metode belajar sebagaimana yang dilakukan oleh para ulama hadis terdahulu dengan melakukan kunjungan ke beberapa daerah. Dalam konteks pendidikan di SD, metode rihlah ilmiah bisa dilakukan guru PAI dengan mengajak murid-muridnya ke beberapa tempat yang memiliki nilai sejarah dan edukatif, karena masa SD merupakan masa dimana anak memiliki rasa penasaran terhadap semua hal.

Oleh karena itu, pembelajaran PAI tidak hanya dilakukan di dalam kelas, tetapi bisa juga di luar kelas dengan menggunakan media apapun yang ada di alam semesta, termasuk dengan melakukan rihlah ilmiah ke tempat yang memiliki nilai pendidikan, lembaga pendidikan Islam seperti pondok pesantren, museum, atau tempat lainnya yang dirasa memiliki nilai-nilai edukatif untuk dikunjungi.

Dengan sering melakukan rihlah ilmiah, potensi akal akan selalu berkembang dengan mendapatkan informasi-informasi baru yang ditemukan di lapangan. Selain itu, kesehatan anak akan berkembang karena dengan mengadakan rihlah otomatis menjadikan anggota tubuh anak terus bergerak. Setelah melakukan rihlah, guru PAI membimbing anak untuk mendiskusikan apa yang telah mereka dapat, saat melakukan diskusi, disinilah peran guru PAI mesti bisa mengembangkan potensi akal setiap anak untuk berfikir, serta melatih setiap anak percaya diri untuk berbicara dan menyatakan pendapatnya. 
Tatang, Syahidin, Ahmad. Filsafat Metode Mengajar Omar...

Dalam sesi diskusi, guru PAI bisa menggunakan metode lingkaran (halqah) supaya tercipta kedekatan antara guru dan murid. Kemudian bisa diadakan dialog, perbincangan, belajar mendengar satu sama lain, belajar membaca apa yang disampaikan, bisa juga dengan menuliskannya, hingga menghafalkan setiap yang disampaikan oleh guru. Selanjutnya guru PAI bisa membandingkan dari setiap pendapat yang disampaikan oleh murid, sehingga timbul pemahaman bersama berdasarkan hasil diskusi.

Setelah ditemukan pemahaman bersama hasil rihlah ilmiah melalui diskusi, kemudian guru PAI menyimpulkan hasil diskusi yang dilakukan. Evaluasi dalam pembelajaran PAI tidak mesti harus terukur dan terindera melalui tes tertulis, tetapi bisa dengan menggunakan berbagai macam metode evaluasi, salah satunya dengan melihat dan mengamati perkembangan akhlak peserta didik selama proses pembelajaran berlangsung (Hidayat \& Asyafah, 2019). Dengan demikian, ranah kognitif, afektif, dan psikomotorik akan tercakup semuanya.

Jika setiap guru PAI sudah terbiasa menggunakan berbagai macam metode pembelajaran, salah satunya konsep metode mengajar al-Syaibany yang dirasa cukup kaya untuk diamalkan, nantinya akan timbul perasaan rindu dari para murid untuk kembali berjumpa dengan mata pelajaran PAI, karena setelah belajar PAI akan dirasakan kesan yang bermakna, dimana didalamnya ada kedekatan antara guru dan murid, yang selama ini dirasakan kurang dalam pembelajaran modern.

Jika sudah ada sambungnya hati antara guru dan murid, nantinya akan ada keikhlasan untuk saling mendo'akan dalam setiap sujudnya, guru akan selalu mendo'akan muridnya, begitupun smurid akan selalu mendo'akan gurunya, sehingga akan timbul kedekatan batin antara guru dan murid. Jika sudah ada kedekatan batin antara keduanya, nantinya akan timbul perasaan saling merindukan antara guru dan murid, meskipun pelajaran PAI hanya 1 kali seminggu, namun waktu tersebut akan terasa lama dirasakan oleh guru dan muridnya. Dengan demikian, kunci dalam kesuksesan dalam pembelajaran adalah bagaimana caranya ada keikhlasan antara guru dan murid dalam proses pembelajaran.

Hidayat \& Syahidin (2019) peran guru mesti menyampaikan materi PAI yang lebih aktual, realistis, menyenangkan, mencerahkan, mencerdaskan, dan membangkitkan peserta didik. Kesan setelah belajar PAI harus mampu memberikan perubahan terhadap 
Tatang, Syahidin, Ahmad. Filsafat Metode Mengajar Omar...

cara berfikir, karena melibatkan fisik dan mental sehingga materi yang diterima pun mampu mencerdaskan pemikiran peserta didik. Hasilnya pembelajaran PAI tidak akan berkesan sebagai pembelajaran yang kurang menarik, tetapi justru sebaliknya, peserta didik akan akan memiliki motivasi lebih dan senang jika belajar PAI

Dengan demikian, metode pembelajaran sebagaimana dirumuskan al-Syaibany setidaknya bisa menjadi solusi untuk memberikan inovasi dalam pembelajaran PAI yang selama ini monoton kekurangan metode. Kesan belajar PAI yang awalnya membosankan bisa menjadi menyenangkan, berkesan, dicintai, dan dirindukan para murid, terutama pada jenjang SD. Kuncinya ada dalam keikhlasan dalam mengajar yang berdasarkan kasih sayang, sehingga dari sana akan timbul proses pembelajaran yang menyenangkan tanpa beban.

\section{SIMPULAN}

Filsafat metode mengajar pada pendidikan Islam menurut Omar Mohammad alToumy al-Syaibany memiliki landasan filosofis yang kuat dan komprehensif. Didalamnya sudah mencakup berbagai metode mengajar yang akan mencakup ranah pengetahuan, sikap, dan keterampilan. Dengan menggunakan metode mengajar yang digagas al-Syaibanya, setidaknya bisa menjadi solusi untuk memberikan inovasi dalam pembelajaran PAI yang selama ini monoton dan kekurangan metode. Kesan belajar PAI yang awalnya membosankan bisa menjadi menyenangkan, berkesan, dicintai, dan dirindukan para murid, terutama pada jenjang SD.

Konsep filsafat metode mengajar menurut al-Syaibany perlu dipelajari, dipahami, dihayati, dikembangkan dan diimplementasikan dalam pendidikan modern saat ini yang sudah kehilangan makna esensial, salah satunya melalui lembaga pendidikan formal jenjang SD yang memiliki peran sangat sentral dalam membina akhlak mulia.

\section{UCAPAN TERIMA KASIH}

Terima kasih kepada Prof. Dr. Syahidin, M. Pd. dan Dr. Ahmad Syamsu Rizal, M. Pd. selaku penulis kedua dan ketiga yang telah membimbing dalam penulisan naskah ini. 
Tatang, Syahidin, Ahmad. Filsafat Metode Mengajar Omar...

\section{DAFTAR RUJUKAN}

Al-Syaibany, O. M. al-T. (1983). Falsafah Tarbiyah al-Islamiyah. Mesir.

Al-Syaibany, O. M. al-T. (1979). Falsafah Pendidikan Islam. Jakarta: Bulan Bintang.

Fikri, M. (2011). Konsep Pendidikan Islam; Pendekatan Metode Pengajaran. Jurnal Ilmiah Islam Futura, XI(1), 116-128.

Hasib, K. (2014). Filsafat Ilmu dan Problem Metodologi Pendidikan Islam. Jurnal AtTa'dib, 9(2), 143-159.

Herman. (2014). Prinsip-Prinsip Dalam Pendidikan Islam (Universal, Keseimbangan, Kesederhanaan). Jurnal Al-Ta'dib, 7(2), 99-119.

Hidayat, T., \& Asyafah, A. (2018). Paradigma Islam Dalam Metodologi Penelitian dan Implikasinya Terhadap Penelitian Pendidikan Agama Islam. Tadrib, IV(2), 225245. https://doi.org/https://doi.org/10.19109/tadrib.v4i2.2507

Hidayat, T., \& Asyafah, A. (2019). Konsep Dasar Evaluasi dan Implikasinya dalam Evaluasi Pembelajaran Pendidikan Agama Islam di Sekolah. Al-Tadzkiyyah: Jurnal Pendidikan Islam, 10(I), 159-181.

Hidayat, T., \& Kosasih, A. (2019). Analisis Peraturan Menteri Pendidikan dan Kebudayaan Republik Indonesia Nomor 22 tahun 2016 Tentang Standar Proses Pendidikan Dasar dan Menengah Serta Implikasinya Dalam Pembelajaran PAI di Sekolah. Murobbi : Jurnal Ilmu Pendidikan, 3(1), 45-69.

Hidayat, T., Rahmat, M., \& Supriadi, U. (2019). Makna Syukur Berdasarkan Kajian Tematik Digital Al-Quran dan Implikasinya dalam Pendidikan Akhlak di Sekolah Dasar. Pendas : Jurnal Ilmiah Pendidikan Dasar, IV(1), 94-110.

Hidayat, T., Rizal, A. S., \& Fahrudin. (2018a). Pendidikan Dalam Perspektif Islam dan Peranannya Dalam Membina Kepribadian Islami. Jurnal Mudarrisuna: Media Kajian Pendidikan Agama Islam, 8(2), 218-244. https://doi.org/http://dx.doi.org/10.22373/jm.v8i2.3397 0 Ta

Hidayat, T., Rizal, A. S., \& Fahrudin. (2018b). Peran Pondok Pesantren Sebagai Lembaga Pendidikan Islam di Indonesia. Ta'dib : Jurnal Pendidikan Islam, VII(2), $1-15$.

Retrieved from

https://ejournal.unisba.ac.id/index.php/tadib/article/view/4117/2485

Hidayat, T., Rizal, A. S., \& Fahrudin. (2018c). Pola Pendidikan Islam di Pondok Pesantren Mahasiswa Miftahul Khoir Bandung Dalam Membentuk Kepribadian 
Tatang, Syahidin, Ahmad. Filsafat Metode Mengajar Omar...

Islami. Ta'dib: Jurnal Pendidikan Islam, VII(1), 9-19. Retrieved from https://ejournal.unisba.ac.id/index.php/tadib/article/view/3770/2247

Hidayat, T., \& Suryana, T. (2018). Menggagas Pendidikan Islam: Meluruskan Paradigma Pendidikan di Indonesia. Jurnal Pendidikan Islam Indonesia, 3(1), 7591. Retrieved from http://ojs.pps-ibrahimy.ac.id/index.php/jpii/article/view/133/93 Hidayat, T., \& Syafe'i, M. (2018a). Filsafat Perencanaan dan Implikasinya dalam Perencanaan Pembelajaran Pendidikan Agama Islam di Sekolah. Lentera Pendidikan, $21(2)$ 188-205.

https://doi.org/https://doi.org/10.24252/lp.2018v21n2i5

Hidayat, T., \& Syafe'i, M. (2018b). Peran Guru Dalam Mewujudkan Tujuan Pembelajaran Pendidikan Agama Islam di Sekolah. Rayah Al-Islam : Jurnal Ilmu Islam, 2(1), 101-111.

Hidayat, T., \& Syahidin. (2019a). Education Values Based On The Thinking Of KH. Choer Affandi And Their Relevance To The Modern Education (The Study of The Legendary Islamic Scholar of Pondok Pesantren Miftahul Huda Manonjaya, Tasikmalaya). Tadris: Jurnal Pendidikan Islam, 14(1), 27-39.

Hidayat, T., \& Syahidin. (2019b). Inovasi Pembelajaran Pendidikan Agama Islam Melalui Model Contextual Teaching And Learning Dalam Meningkatkan Taraf Berfikir Peserta Didik. Jurnal Pendidikan Agama Islam, XVI(2), 115. https://doi.org/10.14421/jpai.2019.162-01

Hidayat, T., Syahidin, \& Rizal, A. S. (2019). Prinsip Dasar Falsafah Akhlak Omar Mohammad Al - Toumy Al - Syaibany dan Implikasinya dalam Pendidikan di Indonesia. Jurnal Kajian Peradaban Islam, 2(1), 10-17. Retrieved from http://www.jkpis.com/index.php/jkpis/article/view/13/10

Juwariyah. (2004). Islam dan Filsafat Ilmu Dalam Pengembangan Pendidikan. Kependidikan Islam, 2(1), 3-22.

Mardeli. (2011). Konsep Al-Qur`an Tentang Metode Pendidikan Islam. Ta'dib, XVI(1), $1-18$.

Mukalam. (2013). Postmodernisme dan Filsafat Pendidikan Islam. Jurnal Pendidikan Islam, 2(2), 285-306. https://doi.org/10.14421/jpi.2013.22.285-307

Mulkhan, A. M. (2013). Filsafat Tarbiyah Berbasis Kecerdasan Makrifat. Jurnal Pendidikan Islam, 2(2), 219-239. https://doi.org/10.14421/jpi.2013.22.219-239 
Tatang, Syahidin, Ahmad. Filsafat Metode Mengajar Omar...

Muslih, M. (2011). Pendidikan Islam dalam Perspektif Filsafat Ilmu. Hunafa: Jurnal Studia Islamika, 8(1), 53-80.

Nursikin, M. (2016). Aliran-Aliran Filsafat Pendidikan dan Implementasinya Dalam Pengembangan Kurikulum Pendidikan Islam. Attarbiyah, I(2), 303-334. https://doi.org/10.18326/attarbiyah.v1i2.303-334

Rahman, H. A. (2012). Pendidikan Agama Islam dan Pendidikan Islam - Tinjauan Epistemologi dan Isi - Materi. Jurnal Eksis, 8(1), 2053-2059.

Rohinah. (2013). Filsafat pendidikan Islam; Studi Filosofis Atas Tujuan dan Metode Pendidikan Islam. Jurnal Pendidikan Islam, 2(2), 309-326. https://doi.org/10.14421/jpi.2013.22.309-326

Syahidin. (2009). Menelusuri Metode Pendidikan Dalam al-Quran. Bandung: Alfabeta.

Syihabuddin, M. A. (2017). Studi Komparatif Filsafat Pendidikan Islam dan Barat. Jurnal Jalie, 01(01), 68-93.

Tolchah, M. (2015). Filsafat Pendidikan Islam: Konstruksi Tipologis Dalam Pengembangan Kurikulum. Tsaqafah: Jurnal Peradaban Islam, 11(2), 381-398. https://doi.org/10.21111/tsaqafah.v11i2.274

Ulfah, M. (2012). Mekanisme Perolehan Ilmu Dalam Perspektif Filsafat Pendidikan Islam. Jurnal Ilmiah Didaktika, XII(2), 289-307.

Yapono, A. (2015). Filsafat Pendidikan dan Hidden Curriculum dalam Perspektif KH. Imam Zarkasyi (1910-1985). Tsaqafah: Jurnal Peradaban Islam, 11(2), 291-312. https://doi.org/http://dx.doi.org/10.21111/tsaqafah.v11i2.270 